\title{
A Coxian Critical Reflexive Lens as a Methodological Tool for Analysis In Liberal Peacebuilding Research in Sri Lanka
}

\author{
Ramya Chamalie Jirasinghe \\ Deputy Director of the US-Sri Lanka Fulbright Commission
}

\begin{abstract}
:
There is an ongoing debate between the neo-positivist researchers who insist that IR research should follow positivist methodologies and the post-positivist researchers in subfields such as feminist and critical studies in IR who insist that the very selection of a methodology is a positioning of power and a validation of a truth through the knowledge the methodology enables. The selection of methodology, the process used to create knowledge, is therefore a decision to position a particular body of knowledge over another. The selection of a particular method over another is an act of enabling a body of knowledge, a truth, and therefore an act of power that can disrupt an entrenched order or destabilize it. This paper explores Coxian critical analysis in IR research and discusses the use of Coxian analysis in exploring the Sri Lankan conflict in a setting of liberal peacebuilding critique. The paper concludes that a critical methodology such as Coxian analysis enables a researcher to question the epistemological and ontological assumptions that have been prevalent in analyzing the Sri Lankan conflict.
\end{abstract}

Key Words: Cox, Liberal, Peacebuilding, Critique, Sri Lanka, Conflict.

\section{Introduction:}

Theory and methodology are interlinked. A research problem explored from a problemsolving theoretical framework will adopt a positivist methodology, while research that critically engages with its subject will turn to "hermeneutics and Ideologiekritik" (Devetak, 2005, p. 145).

Sprinz and Yael (2004, p. 1) identify, case study, quantitative and formal, as the three methodologies that are used in IR research. Where theory provides clear and accurate explanations of phenomena, methodology forms the structured and codified ways to test these theories (Sprinz \&Yael, 2004, p. 4). Whatever methodology that is chosen for a research project from the list of three given by Sprinz and Yael (2004), which are case study, quantitative and formal models, the decision to choose a particular methodology needs to be guided by the characteristics of the phenomena the study is trying to examine (Bennett \& Elman, 2006). 
FGS - CJMR Colombo Journal of Multi - Disciplinary Research

There is an ongoing debate between the neo-positivist researchers who insist that IR research should follow positivist methodologies and the post-positivist researchers in subfields such as feminist and critical studies in IR who insist that the very selection of a methodology is a positioning of power and a validation of a truth through the knowledge the methodology enables (Aradau \& Huysmans, 2013; Geller \& Vasques. 2004; Gerring, 2011; Tickner, 2005). The selection of methodology, the process used to create knowledge, is therefore a decision to position a particular body of knowledge over another. As Tickner (2005) points out, the decision to ask questions not commonly asked in IR, required the feminist IR researchers to formulate and amalgamate methodologies, to enable new epistemologies and to review existing ontologies. Methods ${ }^{1}$ therefore play performative and political roles (Aradau \& Huysmans, 2013, p.3). The selection of a particular method over another is an act of enabling a body of knowledge, a truth, and therefore an act of power that can disrupt an entrenched order or destabilize it.

This paper proceeds as follows. It first discusses the debates around critical methodology in IR research and then outlines Coxian critical theory and Coxian historical analysis. The paper then provides a brief introduction to the contemporary critique of liberal peacebuilding. The paper finally examines the need for critical methodology in peacebuilding research in Sri Lanka.

\section{Critical Methodology in IR:}

The editors of the 2013 European Journal of International Relations' special issue "End of International Relations Theory?", called for an "integrative pluralism” of IR theory (Dunne, Hansen \&Wight, 2013). They argue that moving away from the theoretical pluralism versus fragmentation divide, to an integrative pluralism, will allow IR to explore the complex problems and phenomena it deals with in a holistic and multifaceted manner (Dunne, Hansen \& Wight, 2013). In response, Hamati-Ataya (2013) argues that pluralism and integration in IR theory have prevented a genuine critical discourse on the phenomena being explored. Hamati-Ataya (2013) points out that the

\footnotetext{
${ }^{1}$ See Jackson (2011) for a discussion on the difference between methodology and method and their implication on IR research.
} 


\section{A Coxian Critical Reflexive Lens as a Methodological Tool for Analysis In Liberal Peacebuilding Research in Sri Lanka}

"critical" focusing is limited to a criticism of the events, arrangements and outcomes, instead of being based on Critical Theory that is reflective of the constructs within which the phenomena are occurring. As Hamati-Ataya (2013) points out:

A theory that 'criticizes' social reality but excludes the critique of thought, truth, theory, and science as components of that reality is only very minimally 'critical', and of no significant value to any serious reflexive project in IR.

(Hamati-Ataya, 2013)

The fundamental basis of critical IR theory is “...the idea that the study of international relations should be oriented by an emancipatory politics" (Devetak, 2005, p. 137). Modern critical theory, which emerged from the Frankfurt School, ${ }^{2}$ focuses on the need to understand the challenges faced by people in contemporary society as being a result of a historical trajectory, which could be resolved by understanding the inherent characteristics of the structures that enabled them. This understanding was to be used for dismantling historical structures and systems that subjugated and disempowered people. The other defining characteristic of critical theory is its recognition that knowledge creation, therefore theory, was also a product of society. This meant that critical theory and the theorist, even as they were trying to develop a theory of society, needed to be reflexive of their own parameters (see Devetak, 2005, p. 139; Wiggershaus, 1995, p.542). However, the Frankfurt school theorist did not address the international system in their analyses, yet their theories influenced the critical international theorists such as Robert W. Cox who emerged in the 1980s.

Cox, who pioneered critical international theory, drew from the work of Horkheimer of the Frankfurt School, and differentiated critical theory of the international sphere from traditional (problem solving - in Coxian terms) theory, which is bound by positivist

\footnotetext{
${ }^{2}$ The Frankfurt School (Institute of Social Research) was founded in 1923 in Frankfurt am Main, Germany, with a donation from the wealthy son of an industrialist who wanted to see Marxism developed into a radical system, relevant to the times. During the $2^{\text {nd }}$ World War, the school was forced to close down under the Nazi leadership, and it was relocated to the University of Columbia in the USA but returned to Frankfurt in the 1950s. The school had an unprecedented impact on many fields of study such as sociology, psychoanalysis, music, film studies, literature, as well as social (especially violent student) movements and intellectual traditions in its evolution over five decades (see McLaughlin,1999 and Wiggershaus, 1995, for discussions on the evolution of the school, its key thinkers, theories and impact).
} 
FGS - CJMR Colombo Journal of Multi - Disciplinary Research

methodology and a preference towards legitimizing the prevailing social-political order (Devetak, 2005, p. 141). Cox made a distinction between theory that functions as a guide to solving a particular problem that is being observed, from theory that is reflective of its own perspective in the approach to the problem (Cox, 1981, p. 128). The fundamental difference in the two types of approaches to a problem lies in that the former takes the existing social, institutional and power dynamics as the established boundaries of the problem, while the latter steps aside from these boundaries and questions how those dynamics came into being (Cox, 1981, p. 129). Cox argued that problem solving theory enabled the neo-liberal international system to exist by situating itself in the nexus of the state system, the global economic system and the global ecosystem, and making itself the ideological basis of analysis (Cox, 1992a; Cox, 1992b). Cox views the end of the cold war not as an "end of history" (and the end of the clashes between economic and political systems), but as the beginning of an era when the political and economic orders would be severed from each other, leaving people, especially the marginalized and disadvantaged, feeling alienated in the society they live in (Cox,1992a). To Cox, this is the crisis of democracy in the neo-liberal system:

Today, a different kind of crisis affects democracies: a disillusionment of people with political leadership, a turning away from politics with a certain disgust, an association of politics with corruption, a sense that politics doesn't really matter except to the politicians, a widespread depoliticization. ....

It is difficult not to see a correlation between the success of the new capitalism and this effect of depoliticization. By removing the economic sphere from political control--whether this is achieved by law or by ideology--what determines the condition of people in their everyday lives is removed from their control. Politics becomes irrelevant. The sense of civic efficacy is removed; and many people, the most disadvantaged, are left in the futility of alienation. Their rage is unchannelled, ineffective, selfconsuming. It marks an impasse. It does not herald the construction of a future.

$$
\text { (Cox, 1992a, p. 8) }
$$

It is because of this crisis of democracy, engendered by the neo-liberal global order, and ignored by multilateral institutions in their effort to deal with immediate problems, that critical international theory becomes most pertinent. A new order will need to be built, from the grassroots upwards when the existing order fails and is transformed when it 


\section{A Coxian Critical Reflexive Lens as a Methodological Tool for Analysis In Liberal Peacebuilding Research in Sri Lanka}

cannot control the system from top down (Cox, 1992a, p.11). A critical international framework turns the research away from the problem solving discourse of the IC towards one that examines the boundaries and epistemological foundations that theoretically justify that order.

\section{Coxian Critical Theory:}

The "turn" in IR studies from a positivist, a-historical-problem solving framework, to a post-positivist critical framework has a clearly distinguishable moment: Robert W. Cox's publication of his seminal essay, "Social Forces, States and World Orders: Beyond International Relations Theory”, in 1981 (see Burchill \& Linklater, 2005, p.14; Leysens, 2008 , p. 4). ${ }^{3}$ Much of the power-based contemporary liberal peace critique is grounded in Coxian critical theory (Chandler, 2011, p. 176).

Problem solving theory, as opposed to critical theory, needs to be understood as arising from a particular historical context, therefore, the manner in which it proposes to solve the problem is constructed from within its context and precludes questioning as to whom the theory serves (Cox in Schouten, 2009, p. 5). The most important aspects of the problem solving theoretical approach is its assumption of the fixity of the dynamics of a setting and that it does not acknowledge its ideological basis, but attempts to solve a problem to ensure that ideological foundation can be perpetuated (Cox, 1981, p. 130). The framework of problem solving theory is value bound, since it does not question the framework within which it exists, despite using the positivist methodology of stabilizing its variables, and is therefore not value free as it claims to be (Cox, 1981, p. 130; Leysens, 2008, p.20). For Cox, the problem solving theoretical basis equalled positivism, which he associated with the neo-realism (Cox, 1981, p. 131; Leysens, 2008, p. 41; Mittelman, 1998, p. 63).

On the other hand, critical theory attempts to be aware of the perspective it takes, and questions the framework from which it explores a situation to draw a holistic account of

3 See Mittelman (1998), Devetak (2005) and Leysens (2008) for a discussion on the theoretical developments made by the Frankfurt School, Linklater, Richard Ashley, Foucault, Bourdieu and others, at the time, whose work challenged the standard neorealist and state centric thinking of the cold war. 
FGS - CJMR Colombo Journal of Multi - Disciplinary Research

the dynamics at play (Cox, 1981, p. 129). In critical theory, the initial problem leads to a "contemplation" of the bigger picture of which it is a part and will lead to attempts to explore the manner in which the issue at hand and the larger canvas are dialectically interconnected in a process of change (Cox, 1989, p. 129). Coxian Critical Theory however, does not ignore the value of problem solving theory and of looking for causal reasons (Leysens, 2008, p. 41; Unay, 2010, p. 42). In exploring a problem such as climate change, Cox points out how problem solving theory will enable the globe to find solutions to the energy crisis and develop renewable sources of energy (Cox in Schouten, 2009, p. 6). Critical theory, on the other hand, will explore the wider network of factors that are at play, ranging from Western religious thinking that posits nature is a resource created for the service of humans, to Enlightenment-modernist thinking that assumes that nature is a force that can be controlled by humans (Cox in Schouten, 2009, p. 6). Cox discusses how problem solving can be the springboard for critical analysis:

With the example of climate change, the question is not to choose between problem-solving or critical theory. Problem solving theory is practical and necessary since it tells us how to proceed given certain conditions (for instance, the consequences to be expected from carbon generated from certain forms of behavior in terms of damage to the biosphere). Critical theory broadens the scope of inquiry by analyzing the forces favoring or opposing changing patterns of behavior.

(Cox in Schouten, 2009, p. 6)

As pointed out by Cox, it is useful to begin with the immediate event from a problemsolving basis and then move onto the wider critical frame.

Coxian Critical Theory has two key sets of concepts on structures: "power and production"; and "hegemony ${ }^{4}$, state and civil society" (Mittelman, 1998, p. 67; Unay, 2010 , p.40). In critical theory the dynamic between the structures is analyzed through a lens called "historicism", to understand the nature of a current event. Cox points out:

\footnotetext{
${ }^{4}$ Cox expanded Gramschi's term, "hegemony" (Forgacs, 2000), into a "neo-Gramscian approach" in IR analysis to incorporate the relationship between the state, the global order and civilians (see Unay, 2010 for an analysis of the World Bank using a Coxian neo-Gramscian framework).

The concept of "hegemony" in contemporary IR has several faces which are "as the production of coercion, the production of consent, the production of attraction and the production of life" (Antoniades, 2008, p.11). However, as Antoniades argues (2008, p.2), the common characteristic of all IR approaches to the concept is that: "the concept of hegemony may imply a great capacity for coercion and/or a great degree of influence or control of the structures of the international system and the international behaviour of its units, but it excludes situations where we have the establishment of relations of direct and official control of foreign governments or territories".
} 


\section{A Coxian Critical Reflexive Lens as a Methodological Tool for Analysis In Liberal Peacebuilding Research in Sri Lanka}

"Critical theory is a theory of history in the sense of being concerned not with the past but with a continuing process of historical change" (Cox, 1981, p. 129). In critical theory, "historical structures", which are ideas, institutions and material capabilities, are constantly in a dynamic process of configuration (Cox, 1981, p. 136). The material capabilities (power) are the ability to transform technological and natural resources into productive or destructive forces. Ideas are the subjective collective images and norms of behavior of a group of people. Institutions become the means by which ideas are stabilized and which then take on an existence of their own. Historical structures can be applied at three levels; at production level (social forces), state level (forms of state) and world-order (world orders) level, all three of which are also interconnected (Cox, 1981, p. 138). Hegemony, therefore, is a dynamic interplay between the three historical structures and at the different levels. Institutions, for instance, gain hegemony when ideas and material power enable their consolidation without coercion (Leysens, 2008, p. 48). State hegemony, exists legitimately by deriving hegemony from the interaction between material capability, institutions and ideas (Cox, 1981, p. 139; Leysens, 2008, p. 48; Unay, 2010, p. 42). The state, society and the global order are, in a constant dialectic with each other (Mittelman, 1998, p. 70).

\section{Coxian Historicism}

Cox's theory on historical structures offers a means to investigate the dialectic between material capabilities, institutions and ideas and how their interaction can enable a change in a particular context (Cox, 1981, p. 137) (See figure 1). As Cox points out, the relationship of the three forces are reciprocal, and the "question of which way the lines of forces will run is always an historical question to be answered by a study of a particular case" (Cox, 1981, p. 136).

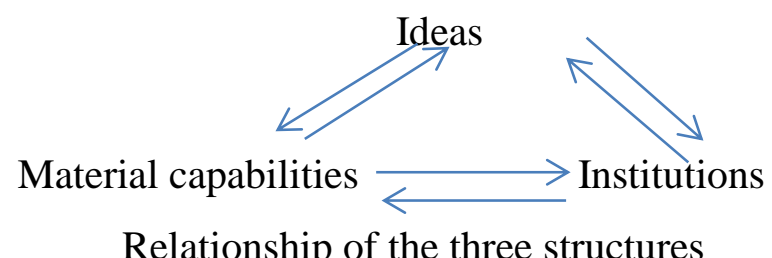

(Cox,1981, p. 136) 
FGS - CJMR Colombo Journal of Multi - Disciplinary Research

Berry points out that Cox's use of ideas as one of the important forces in this triumvirate that positions agency as an influencing aspect that impacts on material capabilities and institutions (Berry, 2007, p. 13). Cox (1981, p. 136) describes two types of ideas: intersubjective ideas (shared notions of how society is organized that produce continued habits and beliefs) and collective images of social order (these are held by different people that become the medium for discourses both shard and opposed). Cox also points out that the dialectic nature of the three forces, while a limited to, and simplified aspect of a greater totality, differentiates the historical structures methods of analysis from the positivist, problem-solving framework's ceteris paribus (Cox, 1981, p. 137).

Cox (1981, p. 137) suggests the use of the historical structures method through the following process:

1. By first defining each particular structure: this needs to be made, not from a set formulaic definition of a structure, but by exploring the historical situation within which it is set.

2. This needs to be followed by looking at the emerging rival structures that may offer alternative structures and new developments.

3. Each set of structures can be applied at three levels: social forces (production processes), forms of state (the complex interplay between the state and the society) and world orders (the configuration of forces that can resolve the problem of war or peace for a collection of states). These three levels, too, dialectically interact with each other, with a change in one impacting the other and creating a reconfiguration.

Cox, brings the historical structures and the three levels together by defining their interrelationship and dialectic co-creativity:

Considered separately, social forces, forms of state and world orders can be represented in a preliminary approximation as a particular configuration of material capabilities, ideas and institutions (as indicated in figure 1).

Considered in relation to each other, and thus moving towards fuller representation of historical process, each will be seen as containing, as well as bearing the impact of, the others...

Cox (1981, p.137) 


\section{A Coxian Critical Reflexive Lens as a Methodological Tool for Analysis In Liberal Peacebuilding Research in Sri Lanka}

4. Barry (2007, p. 19), points out that Cox's historical structures methods enables the researcher to give both primacy and interactivity to ideational structures as they can cause material outcomes.

5. The stability of a particular level and persistence of a particular configuration of historical structures are linked by Cox to hegemony (defined by Cox as the production of consent). He equates structural stability to the concept of hegemony (Cox, 1981, p.139). And concludes that, "The notion of hegemony is a particular fit between power, ideas and institutions..."(Cox, 1981, p. 140).

6. In order to decide if the historical structure of one of the levels has collapsed and a structural transformation has taken place, Cox recommends that the analyst asks the following two questions (Cox, 1981, p. 144):

1. "...what are the mechanisms for maintaining hegemony in this particular historical structure?”

2. "...what social forces and forms of state have been generated within it, which could oppose and ultimately bring about a transformation of the structure?"

\section{Liberal Peace Critique, Hybridity and the 'Local-Everyday'.}

Contemporary liberal peacebuilding critique draws from the IR critical theoretical framework, and has enlarged its critical framework to incorporate the analytical tools offered by a range of other disciplines: subaltern studies, postcolonial studies and development studies (Tom, 2012, p. 12; Richmond \& Mac Ginty, 2014, p. 11). The current liberal peacebuilding critical discourse can be divided into a "“"power based" critique' and “"ideas based” critique” (Chandler, 2011, p. 176). The power based critique argues that liberal peace is a means by which Western states consolidate their global hegemony, while the ideas based critique point out the problematic of the universal assumptions inherent in the liberal peace thesis and normative problems of policy and practice (Chandler, 2011, p.176, p. 178). Within the field of liberal peacebuilding, the "emancipatory" critique, which ranges from an outright dismissal of peacebuilding on the grounds of its Western, neo-colonial orientation, to a call for a transformed alternative, has engendered much debate and division (see Paris, 2011, p. 161). This debate can be framed within a question of whether there is an alternative to liberal peacebuilding. As 
FGS - CJMR Colombo Journal of Multi - Disciplinary Research

Paris (2011, p. 166) points out, solutions such as outright international governance or adaptation to a local model, have not been clear alternatives and therefore some form of liberal peace remains the foundation of much of the critical debate. However, as Paris one of the leading academics of the ideas/policy based critique (Chandler, 2011, p.179), says: "The greatest strength of critical approaches has always been their focus on exposing and dissecting widely held assumptions and orthodoxies" (Paris, 2011, p. 168).

Critics such as Oliver Richmond and Roger Mac Ginty have questioned the very bases of liberal peacebuilding and argued for the need for frameworks for both evaluation and practice. Richmond argues for a post-liberal peace (2011a) and Mac Ginty a hybrid peace (2011). The critique, in effect, emphasizes the need to relook at the bases of power in peacebuilding and questions of the epistemology and the ontology of peace as it is used in IR (Richmond, 2008). As Richmond and Mac Ginty point out:

The most significant contribution made by the critique of the liberal peace has been the construction of a framework of analysis allowing scholars to unpack the evolving nature of various forms of peace activity (Chandler, 2009; Mac Ginty, 2008; Paris, 2004; Richmond, 2005; 2013a).

(Richmond \& Mac Ginty, 2014, p. 4)

Without a critical engagement which takes a macro approach to liberal peace study, Paris argues, it is not possible to ascertain how peace work is interwoven with the larger political dynamics prevalent at the time (Paris, 2010, p. 29). In a defense of liberal peace against the criticisms levelled against it, Paris insists that the need at the moment is not to look for alternative to liberal peace, but to "reform existing approaches within a broadly liberal framework" (Paris, 2010, p. 362). He points that the debate on liberal peace needs to be constructively critical, engaging in studies that ask questions that explore issues such as "legitimacy", obligations of international actors and local ownership of peace (Paris, 2010, p. 363- 364).

The most wide-ranging and significant contribution to the contemporary critical debate, is by Richmond who looks at going beyond the epistemological basis of the liberal peace thesis to develop a post liberal peace that incorporates the local. As he says, the current disarray of liberal peacebuilding, calls for an urgent need to explore the terms, "the local", "the everyday", "the hybrid", and "the infra politics of peacebuilding" (Richmond, 


\section{A Coxian Critical Reflexive Lens as a Methodological Tool for Analysis In Liberal Peacebuilding Research in Sri Lanka}

2011a, p. 13-16). The new, emerging, understanding of words such as agency, the use of language and practices push exiting enlightenment western social science driven assumptions to their boundaries to create a peace that resonates with the recipients (Richmond, 2011a, p. 21). This is the cutting edge of the liberal peacebuilding critique, which calls for a radical rehauling of IR's approach to research agendas, practice and policy, to build a new peace that creates a global order that can incorporate different ways of being locals. The need to be reflective of, and acknowledge the framework within which phenomena occurs, is one of the central aims of critical IR theory. In emancipatory peacebuilding critique, this has opened up areas of research, that explore the ontologies and epistemologies that are taken as a given in liberal peacebuilding practice. Richmond and Mac Ginty (2014, p. 11) point out that one of the main contributions of liberal peacebuilding critique has been the questioning of categories that inform liberal peacebuilding. Categories and concepts such as peace, agency, freedom, are assumed to have universal validity in peacebuilding practice. The use of language in peacebuilding, "good governance", and "capacity building" recreate power dynamics similar to that between the colonizers and the colonized in a modern framework of Western and non-Western (see Richmond \& Mac Ginty 2014; Sabaratnam 2011b). Led primarily by academics such as Oliver Richmond and Roger Mac Ginty, this strand of the liberal peace critique explores the different approaches to peace in a "hybrid peace" (Mac Ginty, 2011) or a "post liberal peace" (Richmond, 2011a). This critique unpacks the manner in which the local and the liberal peace project engage, contest each other and consolidate, and seeks to describe the possibilities this consolidation offers (Tom, 2011, p. 134).

Richmond (2011a, p. 19) defines the local “... to denote what international actors normally perceive as a range of actors and terrains spanning their non-Western and "nonliberal" partners for liberal peacebuilding and state building at the elite level ...". The "local", for Richmond, is not a binary other to the liberal or the international in the form of "illiberal" or the "non-Western". He points out that the local may possess substantial degrees of trans-national and transversal experience in liberal politics (Richmond, 2011a. p. 14). Richmond gives the "local" greater nuance with the term "local-local", to indicate 
FGS - CJMR Colombo Journal of Multi - Disciplinary Research

the diversity of the communities and individuals that make up the local political space as opposed to the "liberally projected artifice of elite and civil society" (Richmond, 2011a, p. 14). The everyday life of the "local" therefore is embedded with the possibilities of contestation, resistance and transformation of the liberal through the "critical agency" the local possess from a range of context specific factors such as identity and customs (Richmond, 2011a, p.16). In this search for an alternative to normative liberal peace practice, the concept of "critical agency" becomes fundamental (Richmond, 2011a, p.17). Critical agency is, therefore, the marginalized's, the local's and the subaltern's repoliticization and reclaiming of their agency in response to the state-centric peacebuilding processes that have failed to take account of their needs (see Richmond, 2011a, pp. 117-150). Richmond situates the "local" within the space he calls the "everyday", both of which, have been traditionally "evacuated" from social science inquiry due to the difficulties it poses on an inquiry for its vagueness, banality, the risk of stereotyping and the opposition it creates to the state or the international (2011a, p. 14). The distancing of peacebuilding practitioners and academics from this ordinary banality of everyday lives of people is a return to colonial intellectual practice that maintains a distance from the subject to ensure a differentiation that confirms an illiberal other (Richmond, 2011b, p. 227). This distancing has engendered a "colonial anxiety" and a local resistance from which, a critical agency emerges, with its inherent possibilities of a post-liberal peace (Richmond, 2011a; 2011b). The post-liberal calls for the international as well the state and its liberal elite practitioner to be open to different forms of being, to focus on needs instead of rights, explore material desires that are described by the individual instead prescribed by the international and the developmental frameworks. Richmond (2011a; 2011b) points out that a post-liberal peace enables the liberal to be united with the local and allows a gradual political transformation from the bottom that will create an equitable global order. Richmond's emancipatory critique provides a window into exploring a local context through the "local-everyday".

Mac Ginty's hybridity provides a window into exploring the hybrid nature of the local context and the hybridization of peace that occurs in interventionist liberal peace processes (Mac Ginty, 2011). The concept of hybridity and hybridization are not new. 


\section{A Coxian Critical Reflexive Lens as a Methodological Tool for Analysis In Liberal Peacebuilding Research in Sri Lanka}

Their roots can be traced to the $19^{\text {th }}$ century, but its emergence in contemporary academia can be traced to the postcolonial critiques, primarily Homi Bhabha (Mac Ginty, 2011, pp. 70-71). Mac Ginty argues that hybridity is not the result of two completely different actions, practices, norms etc., coming together to create a new, third form, but is rather, a complex, variable, multifaceted outcome that is multiple, simultaneous, organic and long drawn (Mac Ginty, 2011, p. 72). Neither is hybridity the amalgamation of "personnel, material techniques and justificatory ideas" that characterize multilateral organizations and peacebuilding mechanisms used by interventionist programmes (Mac Ginty, 2011, p.75). Hybridization can render binary conceptualizations meaningless and words ineffective, but Mac Ginty recognizes that some actors or processes are more hybrid than others in their ability to negotiate or resist the process of transferring or receiving the will of others (Mac Ginty, 2011, p. 73). In liberal peacebuilding, where interventionist peacebuilding projects are introduced to post conflict contexts, hybrid peace is a long drawn out social process that occurs at multiple levels, with multiple media and actors to create a peace that is unlike that imagined through the liberal framework. Mac Ginty points out that a hybrid peace conflicts with the universalizing goals of liberal peace which has resulted in excluding minorities and the disadvantaged. Liberalism and its universalizing and top down reform mechanisms destroy the pluralism that occurs, naturally, on ground in the everyday in a society's own unique means of pluralism and tolerance. Resistance is an aspect of local engagement with and response to liberal peacebuilding mechanism that has large amount of resources and structural power and is not necessarily a binary engagement, and can result in a hybrid, outcome. For all this however, where the post-liberal (Richmond, 2011a) is created through hybridity, Mac Ginty cautions that the possibility of such a peace emerging in a post conflict society is dependent on the quality of the external researchers. He points out that researchers need to be able to step outside their strictures, language and methodologies and use antennae that is able to pick the salient qualities of a society. As Mac Ginty (2011, p. 209) points out: "One of the travesties of contemporary academia is that it has developed ways of discussing peace and conflict that exclude the very societies that are under review." 
FGS - CJMR Colombo Journal of Multi - Disciplinary Research

\section{Critical Methodology in Liberal Peacebuilding Research in Sri Lanka:}

Much of the existing research the conflict in Sri Lanka focuses on assessing liberal peacebuilding mechanisms, policy and intervention outcomes of the attempts at the resolution of the Sri Lankan conflict, from within ideas-problem solving frameworks (see Devotta, 2000, Edirippulige, 2000; Stokke \& Uyangoda, 2011) ${ }^{5}$. A critical theory and methodology allows a researcher to formulate the problem and investigate it as a critique of the existing hegemonic-epistemological framework and ontological assumptions used in peacebuilding scholarship in Sri Lanka. The reseach on liberal peace and liberal peacebuilding in Sri Lanka up to the 1980's is engaged through the lenses of political science and historiography. However, liberal peace principles have been in the Sri Lankan political discourse from the $19^{\text {th }}$ century, with the debates on separation of powers, state reform and electoral representation taking center stage (see Bandarage, 2009, p. 22; Edrisinha, Gomez, et. al., 2008; Mendis, 1956). However the use of "liberal peace" language from the ideological and policy framework of the modern liberal world order for promoting "individual and political freedom, representative democracy, tolerance and those economic arrangements which are most conducive to a free society" (Amaratunga, 1989, p. 3), enters the political discourse only in the 1980s. This can be traced to the inauguration of the Council for Liberal Democracy by a small group of men, some of whom were educated at Oxford University in the United Kingdom. The entry of a distinct liberal discourse into the political scene and the formation of a political party, the Liberal Party, created a liberal theoretical framework that appears at first glance to have brought a fresh framework of analysis for exploring a modality for creating an equitable, secular Sri Lankan society. The liberal discourse that appeared in the 1980s was indeed the first explicit acknowledgement of its framework of analysis, which initially explored state and constitutional reform mechanisms for liberal peacebuilding. That the contemporary local political discourse is embedded in an epistemological framework of liberal peace is, ironically, best depicted in the Interim Report of the Sinhala Commission Report of 1997, which seeks to maintain the political hegemony of the Sinhala-Buddhists. The report develops its arguments for maintaining Sinhala

\footnotetext{
${ }^{5}$ See Chapter Two of this thesis for a detailed exploration of the existing body of work on peacebuilding in Sri Lanka.
} 


\section{A Coxian Critical Reflexive Lens as a Methodological Tool for Analysis In Liberal Peacebuilding Research in Sri Lanka}

Buddhist hegemony based on the liberal peace framework of power separation and democratic principles, especially parliamentary sovereignty, while expressing concerns about the Sinhala Buddhists constituency being divided and weakened (see Edrisinha, Gomez, et. al., 2008: 587, p. 619).

The labeling of the contemporary discourse, as liberal, however, succeeds in veiling the epistemological foundation of much of the previous political, historiography and policy literature on attempts at creating equity for citizens in Sri Lanka. Most, political science, international relations, historiography, and administrative and foreign policy (see Jayawardane, 2004) literature on Sri Lankan have an epistemology of liberal peace and peacebuilding, although the works do not explicitly recognize this foundation. This is particularly relevant as even much of the state reform literature to emerge from a Marxist and "left" basis are grounded in a liberal framework, which is reflected in the policy documents of the early $20^{\text {th }}$ century as well as in the discourse of the $21^{\text {st }}$ century ${ }^{6}$. Their contribution to the discourse on equity for all individuals in Sri Lanka (especially over the issue of the disenfranchisement of the Plantation Tamil workers and the equal use of vernacular languages) is significant (see Edirippulige, 2000, p.157). However, it must be noted that where the "left" politicians turned to federalism as a solution to the ethnic differences, they do so through an ideological logic derived from a Marxist analysis. This analysis, unlike the exploration of liberal mechanisms of their contemporaries, enabled the leaders to map possible social and political transformations that may occur in the future (Edrisinha, Gomez, et. al., 2008, p. 117; Keuneman \& Vaidialingam in Edirisinha, Gomez, et, al., 2008, p. 116). However the power of nationalist politics to override ideological values of the left leaders was highlighted when they capitulated to the majority discourse and joined SWRD Bandaranaike in 1956 to form the Mahajana Eksath Permuka (MEP) in order to stay in power (Edirippulige, 2000, p.157). This capitulation reflects the gap between the liberal discourse and the political ground reality of Sri Lanka. At one end of this spectrum are the national leaders who invariably capitulate their liberal democratic values to the demands of ethno-religious politics when their

${ }^{6}$ See Edrisinha, Gomez, et. al., 2008, pp. 105-120 for the early work by the political leaders espousing a communist ideology who look to federalism as a means for power sharing and http://ravaya.lk/, a broadsheet that has communist roots, but espouses liberal values. 
FGS - CJMR Colombo Journal of Multi - Disciplinary Research

position in power is threatened by an electoral defeat. On the other end are the scholars and policy makers who recognize the damaging impact and the hindrance of local politics on the creation of a liberal peace, who nevertheless approach the issue through a liberal peace problem solving discourse. This highlights the need to reevaluate the epistemological and boundaries of the conflict in Sri Lanka and to explore the source of hegemony in the state ${ }^{7}$.

The overriding epistemological foundation of a liberal peace ideology in the Sri Lankan discourse has a combination of reasons. The formation of the modern Sri Lankan State has a basis in liberal governance through the separation of powers going back to the mid nineteenth century. The epistemological foundation of the Sri Lankan State, starting from its colonial heritage and the educational background of prominent intellectualpolicy makers of the country ${ }^{8}$, to the influencing of sociological research in Sri Lanka, is reflected by the work to emerge from some of the main research institutions of the country (see de Silva J., 2005, p. 536). Acknowledging the epistemological foundation of the existing body of knowledge and state formation is essential to the critical research framework of this thesis.

The war and the conflict in Sri Lanka have attracted a significant group of Sri Lankan, as well as regional and Northern, scholars who have used the Sri Lankan experience to contribute theoretically as well as empirically to the global literature on liberal peacebuilding. This body of literature has paralled the post-cold war genealogy of liberal peacebuilding debates. This has resulted, initially, in a prevalence of work from problemsolving, positivist frameworks of analysis, which have, in the last few decades transitioned to critical constructionist frameworks, mirroring the global liberal peacebuilding critical discourse. This liberal peacebuilding discourse, in turn, has had a

\footnotetext{
7 This comment is based on a Coxian critical framework (Cox, 1981).

${ }^{8}$ SWRD Bandaranaike and Chanaka Amaratunga (both proponents of federalism) were educated at Christ Church and University College, of Oxford University, respectively. Colvin R. de Silva (one of the founder members of the Marxist, Lanka Sama Samaja Party), read for his doctoral dissertation on the British in Ceylon at Kings College, University of London, S. A. Wickremasinghe (the founder of the Communist Party), did his postgraduate studies in medicine at the University of London, and Phillip Gunawardena (a founder member of the Lanka Sama Samaja Party) read economics at the University of WisconsinMadison.
} 


\section{A Coxian Critical Reflexive Lens as a Methodological Tool for Analysis In Liberal Peacebuilding Research in Sri Lanka}

significant influence on policy and practice in the attempts at resolving the conflict and ending the war in Sri Lanka.

The early research, from the start of the armed conflict in the 1980s, included contributions by scholars and commentators primarily in Sri Lanka from IR as well as other disciplines, such as history, political science and anthropology: M. G. A, Cooray; Shelton Kodikara, K. M. de Silva, A. Ariyaratne, Amal Jayawardane, Gamini Keerawella, Mahinda Werake, P. V. J. Jayasekera, Jane Russell, Michael Roberts, Ketheeswaran Loganathan and Jayadeva Uyangoda. Also significant are the few scholars from the North: Patrick Peebles, Richard Gombrich and Bruce Kapferer. With the end of the cold war and the dominance of a liberal peace global agenda, and the persistence of the Sri Lankan conflict, a wider group of Northern scholars and regional scholars too entered the space of knowledge creation on the conflict, war and peacebuilding in Sri Lanka. The period from the late 1980s, through the 2000s saw the entry of Northern theorists and peace PR actioners such as Johan Galtung, John Paul Lederach and Kristian Stokke who introduced and worked from within Northern epistemological frameworks that would dominate the peace processes of Sri Lanka. This period included an influx of scholars and analysts in law and human rights (Rohan Edrisinha, Neelan Tiruchlevam, Deepika Udagama), in history and IR (Sisira Edirippulige, Dayan Jayatilleke, Nayani Melegoda, Chanaka Thalpahewa, Maneesha Wanasinghe-Pasqual, Nira Wickremasinghe,) local political analysts (Chanaka Amaratunga, Rohan Gunaratna, Sinha Ratnatunga).

The gaze of the regional scholars and Northern scholars is also significant as the local reserch on the conflict provided empirical data to the global and regional debates: Neil Devotta, J. N. Dixit, Jonathan Goodhand, S. D. Muni, Urmila Padhnis, H. Shinoda, Jonathan Spencer and Chanaka Thalpahewa. The gradual transition of mainstream liberal peace discourse into a critical constructionist discourse has also had a significant impact on the most recent phase in the genealogy of the Sri Lankan discourse. The scholarship has engaged with issues of peacebuilding through embedded research on the dividends of peace, hybridity and the encounter between the global mechanisms of liberal 
FGS - CJMR Colombo Journal of Multi - Disciplinary Research

peacebuilding and specific encounters with the local by scholars such as: Benedikt Korf, Nayani Melegoda, Camilla Orjuela and Maneesha Wanasinghe-Pasqual.

Much of the literature on liberal peace and peacebuilding in Sri Lanka in the past have engaged with peacebuilding through a problem-solving (Cox, 1981) framework instead of a critical (Cox, 1981) framework. There is a body of research emerging from within a critical/constructivist perspective, examining the impact of liberal peacebuilding on liberal peace and peace in Sri Lanka (Goodhand \& Korf, 2011; Orjuela, 2008). The work of Uyangoda is of relevance here as he has made significant contributions to the critique and pointed out the need for future research based on his studies. He comments "... absence of a class or political force in the majority Sinhalese community to carry out the 'historical task' of resolving the 'national question' with a firm resolve and commitment", and he raises the question as to whether an "external actor [could] play the agential role?" (Uyangoda, 2011, p. 45). Jayatilleka (2013, p. 452) echoes Uyangoda in his comments on the lack of political agency in the Sinhala-Buddhists for searching for a solution to the national question. The existing research, therefore raises the question of agency, peace ownership and intervention, but does not engage with the ontological or epistemological foundations of the issues.

The assumption throughout the peacebuilding processes in postcolonial Sri Lanka has been, in the early phase, that the conflict (then an elites' conflict), could be resolved topdown through reform mechanisms. In its mature phase, where the conflict has been politicized within the electoral discourse, it has been approached from the post-cold war peacebuilding framework of a multi-pronged approach including bottom-up peace creation and ownership mechanisms and top-down reform. Both approaches fail to question the epistemological framework and the ontologies of concepts such as agency and peace in relation to the "everyday-local" as engaged in the global critical scholarship.

\footnotetext{
${ }^{9}$ See the Chapter Three for a discussion of Richmond's (2008) concept of the "local" and "everyday".
} 


\section{A Coxian Critical Reflexive Lens as a Methodological Tool for Analysis In Liberal Peacebuilding Research in Sri Lanka}

Once situated within a critical framework, it is necessary to assess the two segments of the local conflict. The first pertains to the immediate events of the conflict and its continual reconstruction. A critical methodology, however, will allow researchers to explore the liberal peace assumptions on which the peacebuilding attempts of the Sri Lanka conflict have been founded, and trace, instead, the underlying hegemonic bases that guided those assumptions.

The global critique highlights the lacunas as well as possible agendas for research on liberal peacebuilding in a case such as Sri Lanka. The most relevant in this lacuna is the need for case-specific research, based within the critical theoretical framework, which brings in the "local" and the "everyday" to the forefront. Richmond and Mac Ginty (2014, p. 14) identify the need to look at the "most marginal", in other words, the “conflict's subjects" and the need for research into the "nature of hybrid political orders".

In terms of methodology, Richmond and Mac Ginty emphasize that it is “...prudent to get beyond the obsession with levels of analyses, which are of limited worth if we do not seriously examine the epistemologies upon which they are based. Each of the levels is a construction behind which lies a story of our place in the world" (2014, p. 14). Of particular relevance to research on the Sri Lankan confict is Hameri's point that:

...effects of intervention cannot be understood nor evaluated in terms of disembodied ideas of peace or statehood, but only through a historically informed analysis of the development of the actual social and political forces present, as well as the institutions and spaces through which power is contested.

(Hameri, 2011, p. 206)

\section{Conclusion:}

The critical turn in IR, which began in the 1980s, was spearheaded by Robert W. Cox, whose work pioneered critical international theory. Cox drew from the work of Horkheimer of the Frankfurt School, and differentiated critical theory of the international sphere from traditional (problem solving - in Coxian terms) theory, which is bound by positivist methodology and a preference towards legitimizing the prevailing social-political order (Devetak, 2005, p. 141). The value of Coxian analysis, has remined and continues to be acknowledged in contemporary research, and the power-based 
FGS - CJMR Colombo Journal of Multi - Disciplinary Research

critique of liberal peacebuilding acknowledges its debt to Cox. The analytical tools provided by Cox provides a methodological framework for research into the Sri Lankan conflict, which has continued, until very recently to be examined through the framework of liberal peacebuilding. An examination of the epistemological boundaries of the existing research on the conflict in Sri Lanka, displays a body of work that is primarily made of research, that Cox identified as problem solving research and not research that is reflective of the epistemological and ontological assumptions on which it is based. A methodology that seeks to stabilize the world order it is part of. This paper concludes that a shift from problem solving research to critical research, using methodological tools such as that provided by Coxian historicism, will enable the research on the Sri Lankan conflict to expand its epistemological and ontological boundaries. This expansion will enable researchers to identify assumptions and validations that continue to recreate problems and solutions pertaining to the Sri Lankan conflict that remain within the ideological framework of the liberal world order, but have failed to break or end the cycle of contestation, resistance and conflict.

\section{References:}

Amaratunga, C. (Ed.). (1989). Ideas for Constitutional Reform. Dehiwala, Sri Lanka: The Council for Liberal Democracy.

Antoniades, A. (2008). From 'Theories of Hegemony' to 'Hegemony Analysis' in International Relations. Paper presented at the $49^{\text {th }}$ ISA (International Studies Association) Conference, Panel: Hegemony, Security, and Defense in IR, San Francisco, USA. Retrieved, August 14, 2015, from http://core.ac.uk/download/pdf/2709786.pdf.

Aradau, C. \& Huysmans, J. (2013). Critical methods in International Relations: The politics of techniques, devices and acts. European Journal of International Relations, O(0), 1 -24. DOI: $10.1177 / 1354066112474479$

Bandarage, A. (2009). The Separatist Conflict in Sri Lanka: Terrorism, Ethnicity Political Economy. Oxon: Routledge.

Bennett, A., \& Elman, C. (2006). Complex Causal Relations and Case Study Methods: The Example of Path Dependence. Political Analysis, 14(3), Special Issue on Causal Complexity and Qualitative Methods, 250-267. Retrieved March 7, 2014, from http://www.jstor.org/stable/25791852.

Berry, C. (2007). Rediscovering Robert Cox: Agency and the Ideational in Critical IPE. Political Perspectives.1(1), 1-29. Retrieved September 29, 2016, from http://politpriklad.net.ru/files/Rediscovering\%20Robert\%20Cox.pdf 


\section{A Coxian Critical Reflexive Lens as a Methodological Tool for Analysis In Liberal Peacebuilding Research in Sri Lanka}

Burchill, S., \& Linklater, A. (2005). Introduction. In S. Burchill, A. Linklater, R. Devetak, J. Donnely, M. Paterson, C. Reus-Smit \& J. True (Eds),Theories of International Relations ( $3^{\text {rd }}$ Ed., pp. 1-28). Hamshire and New York: Plagrave and MacMillan. Retrieved February 25, 2016, from http://gondayumitro.staff.umm.ac.id/files/2014/09/Theories-ofIR.pdf

Chandler, D. (2011). The Uncritical Critique of 'Liberal Peace'. In S. Campbell, D. Chandler \& M. Sabaratnam (Eds.), A Liberal Peace? The Problems and Practices of Peacebuilding (pp. 174-190). UK: Zed Books.

Cox, R.W. (1981). Social Forces, States and World Orders: Beyond International Relations Theory. Millennium Journal of International Studies, 10(2), 126 -155. Retrieved July 27, 2015. DOI: $10.1177 / 03058298810100020501$.

Cox, R. W. (1992a). Globalization, Multilateralism, and Democracy; the ACUNS 1992 John W. Holmes Memorial Lecture. The Academic Council on the United Nations System (AUCN). Retrieved January 4, 2016, from http://acuns.org/1992-globalizationmultilateralism-and-democracy/

Cox, R. W. (1992b). Multilateralism and World Order. Review of International Studies, 18(2), 161-180. Retrieved, January 4, 2015 from http://www.jstor.org/stable/20097291

Devetak, R. (2005). Critical Theory. In S. Burchill, S., A. Linklater, R. Devetak, J. Donnely, M. Paterson, C. Reus-Smit \& J. True (Eds.), Theories of International Relations ( $3^{\text {rd }}$ Ed.), (pp. 137-159). Hampshire and New York: Plagrave and MacMillan.

DeVotta, N. (2000). Control Democracy, Institutional Decay, and the Quest for Eelam: Explaining Ethnic Conflict in Sri Lanka. Pacific Affairs, 73(1), 55-76.

Retrieved March 6, 2013, from http://www.jstor.org/stable/2672284.

Dunne, T., Hansen, L. \& Wight, C. (2013). Symposium - End of International Relations Theory? End of IR Theory - Companion Symposium for the Special Issue of the International Journal of European Relations. Retrieved August 5, 2015, from http://duckofminerva.dreamhosters.com/2013/09/the-end-of-international-relationstheory.html.

Edirippulige, S.K. (2000). Ethnic Conflict in Sri Lanka: Obstacles to the Peace Process (Doctoral thesis). University of Auckland, Auckland, New Zealand. Available from http://hdl.handle.net/2292/723.

Edrisinha, R., Gomez, M., Thamilmaran V.T., \& Welikala, A. (2008). Power Sharing in Sri Lanka: Constitutional and Political Documents 1926-2008. Colombo and Berlin: Center for Policy Alternatives and the Berghof Foundation for Conflict Studies.

Geller, D.S., \& Vasquez, J. A. (2004). The Construction and Cumulation of Knowledge in International Relations: Introduction. International Studies Review, 6(4),1-6. Retrieved October 8, 2015, http://www.jstor.org/stable/3699722. 
FGS - CJMR Colombo Journal of Multi - Disciplinary Research

Gerring, J. (2011). How Good Is Good Enough? A Multidimensional, Best-Possible Standard for Research Design. Political Research Quarterly, 64(3), 625-636. Retrieved March 14, 2014, from http://www.jstor.org/stable/23056380.

Goodhand, J., \& Korf, B. (2011). Caught in the Peace Trap, pp. 1-15. In J. Goodhand, J. Spencer \& B. Korf. (Eds), Conflict and Peacebuilding in Sri Lanka: Caught in the peace trap? Oxon: Routledge. Available from https://books.google.lk

Hamati-Ataya, I. (2013). Symposium - Defining Theory Down. In End of IR Theory Companion Symposium for the Special Issue of the International Journal of European Relations. Retrieved August 5, 2015, from http://duckofminerva.dreamhosters.com/2013/09/defining-theory-down.html.

Hameiri, S. (2011). A Reality Check for the Critique of 'Liberal Peace'. In Campbell S., Chandler, D. \& Sabaratnam, M. (Eds), A Liberal Peace? The Problems and Practices of Peacebuilding (pp. 191-208). UK: Zed Books.

Jayawardane, A. (Ed). (2004). Documents on Sri Lanka's Foreign Policy: 1947-1965. Colombo: Regional Center for Strategic Studies (RCSS).

Jayatilleka, D. (2013). Long War: Cold Peace - Conflict and Crisis in Sri Lanka. Colombo: Vijitha Yapa.

Leysens, A. (2008). The Critical Theory of Robert W. Cox: Fugitive or Guru? New York: Palgrave Mac Millan. Retrieved January 25, 2016, from http://spmehazem.yolasite.com/resources/the\%20critical\%20theory\%20of\%20robert $\% 20$ cox.pdf

Mac Ginty, R. (2011). International Peacebuilding and Local Resistance: Hybrid Forms of Peace. New York: Palgrave Macmillan.

McLaughlin, N. (1999). Origin Myths in the Social Sciences: Fromm, the Frankfurt School and the Emergence of Critical Theory. The Canadian Journal of Sociology / Cahiers Canadiens De Sociologie, 24(1), 109-139. Retrieved January 4, 2016 from, http://doi.org/10.2307/3341480

Mendis, G.C. (1956). (Ed). The Colebrooke-Cameron Papers: Documents on British Colonial Policy in Ceylon 1796 - 1833. Oxford: Oxford University Press.

Mittelman. J.H. (1998). Coxian Historicism as an Alternative Perspective in International Studies. Alternatives: Global, Local, Political, 23(1),63-92, Retrieved July 17, 2015, from http://www.jstor.org/stable/40644907

Orjuela, C. 2008, Identity Politics of Peacebuilding: Civil Society in War-torn Sri Lanka. New Delhi: Sage. Retrieved August 10, 2015, from https://books.google.lk/

Paris, R. (2010). Saving Liberal Peacebuilding. Review of International Studies, 36, 337-365. Retrieved June 3, 2013, from http://www.jstor.org/stable/40783202

Paris, R. (2011). Critiques of Liberal Peace. In S. Campbell, D. Chandler \& M. Sabaratnam, M. (Eds.). A Liberal Peace? The Problems and Practices of Peacebuilding (pp. 31-54), UK: Zed Books, 


\section{A Coxian Critical Reflexive Lens as a Methodological Tool for Analysis In Liberal Peacebuilding Research in Sri Lanka}

Richmond, O.P. (2011a). A Post-Liberal Peace. UK: Routledge.

Richmond, O.P., \& Mac Ginty, R. (2014, August 20). Where now for the critique of liberal peace?, Cooperation and Conflict, 16 (4), 449-467. Retrieved September 10, 2014, from http://cac.sagepub.com/content/early/2014/08/20/0010836714545691

Sabaratnam, M. (2011a). The Liberal Peace? An Intellectual History of International Conflict Management, 1990-2010. In S. Campbell, D. Chandler, \& M. Sabaratnam (Eds), A Liberal Peace? The Problems and Practices of Peacebuilding (pp.13-30). UK: Zed Books.

Sprinz, D.F., \& Yael W-N. (Eds). (2004). Models, Numbers, and Cases: Methods for Studying International Relation. Ann Arbor: The University of Michigan Press. Retrieved January 25, 2016, from https://books.google.lk/

Stokke, K., \& Uyangoda, J. (Eds). (2011). Liberal Peace in Question: Politics of State and Market Reform in Sri Lanka. UK: Anthem Press.

Tickner, J. (2005). What Is Your Research Program? Some Feminist Answers to International Relations Methodological Questions. International Studies Quarterly, 49(1), 1-21. Retrieved September 11, 2016 from http://www.jstor.org/stable/3693622

Tom, P. (2011). The Liberal Peace and Post-conflict Peacebuilding in Africa: Sierra Leone. Unpublished doctoral thesis, University of St. Andrews. Retrieved August 20, 2013, from http://hdl.handle.net/10023/2469

Unay, S. (2010). Hegemony, Aid and Power: a Neo-Gramscian Analysis of the World Bank. European Journal of Economic and Political Studies, 3(2), 39-52. Retrieved August 14, 2015, from http://ejeps.fatih.edu.tr/docs/articles/107.pdf

Uyangoda, J. (2011). Travails of State Reform in the Context of Protracted Civil War in Sri Lanka. In Stokke, K., \& Uyangoda, J. (Eds) Liberal Peace in Question: Politics of State and Market Reform in Sri Lanka (pp. 35-61). UK: Anthem Press.

Wiggershaus, R. (1995). The Frankfurt School: Its History, Theories and Social Significance. Massachusetts, Cambridge: MIT Press. 